\title{
ADC-1013, an agonistic CD40 antibody optimized for local immunotherapy of cancer
}

\author{
Sara M Mangsbo ${ }^{3}$, Sissela Broos ${ }^{2}$, Erika Gustafsson ${ }^{3}$, Christina Furebring ${ }^{1}$, Niina Veitonmäki ${ }^{1}$, Eva Dahlen ${ }^{1}$, \\ Per Norlen ${ }^{1}$, Malin Lindstedt ${ }^{2}$, Thomas Tötterman ${ }^{3}$, Peter Ellmark ${ }^{1,2^{*}}$ \\ From Society for Immunotherapy of Cancer 28th Annual Meeting \\ National Harbor, MD, USA. 8-10 November 2013
}

Local administration of immune activating antibodies may increase the efficacy and reduce the immunerelated adverse events associated with systemic immunotherapy of cancer. Here we report the development of a fully human agonistic CD40 antibody (IgG1), ADC1013, which has been optimized for local immunotherapy by increasing potency and tumor retention. ADC1013 activates CD40 receptors on antigen-presenting cells such as dendritic cells, resulting in up-regulation of the co-stimulatory molecules CD80 and CD86, and induction of IL-12. In addition, ADC-1013 induces direct tumor killing of $\mathrm{CD} 40+$ tumors, e.g. via antibodydependent cellular cytotoxicity (ADCC). The anti-tumor effects of ADC-1013 were first assessed in a bladder cancer model (EJ) in immunodeficient NSG mice. Significant anti-tumor responses were demonstrated, and further augmented in mice repopulated with human moDCs/T cells. To study the anti-tumor effects related to the immune activating properties of ADC-1013 in more detail, a human $\mathrm{CD} 40$ positive transgenic mouse (hCD40tg) in C57/BL-6 background was used. This transgenic mouse strain has an intact immune system and fully functional dendritic cells that are activated upon ADC-1013 treatment. Furthermore, the dendritic cells obtained from this strain are able to induce antigen specific $\mathrm{T}$ cell activation in vitro upon stimulation with ADC-1013. Importantly, treatment with ADC-1013 in a syngeneic bladder cancer (MB49) model, which is hCD40 negative, demonstrated that ADC-1013 induce significant tumor protection and long term immunity independent of direct tumor targeting. In addition, the anti-tumor immunity was shown to be T-cell dependent. To our knowledge, ADC-1013 represents the first

'Alligator Bioscience AB, Lund, Sweden

Full list of author information is available at the end of the article immunomodulatory antibody optimized for local immunotherapy of cancer. It is currently in late pre-clinical development and will enter clinical trials in 2014.

\section{Authors' details}

${ }^{1}$ Alligator Bioscience $A B$, Lund, Sweden. ${ }^{2}$ Immunotechnology, Lund University, Lund, Sweden. ${ }^{3}$ Immunology, Genetics and Pathology, Uppsala University, Uppsala, Sweden.

Published: 7 November 2013

\section{doi:10.1186/2051-1426-1-S1-P42}

Cite this article as: Mangsbo et al: ADC-1013, an agonistic CD40 antibody optimized for local immunotherapy of cancer. Journal for ImmunoTherapy of Cancer 2013 1(Suppl 1):P42.

Submit your next manuscript to BioMed Central and take full advantage of:

- Convenient online submission

- Thorough peer review

- No space constraints or color figure charges

- Immediate publication on acceptance

- Inclusion in PubMed, CAS, Scopus and Google Scholar

- Research which is freely available for redistribution 